\title{
Frequency of Cardiovascular Risk Factors and Metabolic Syndrome in Patients with Chronic Kidney Disease
}

\author{
Gul Sagun, MD; Gulcin Kantarci, MD; Banu Mesci, MD; Sinem Gungor, MD; \\ Funda Turkoglu, MD; Elif Yorulmaz, MD; and Aytekin Oguz, MD
}

\begin{abstract}
Objective: Metabolic syndrome is a clustering of cardio-metabolic risk factors. Cardiovascular disease is the main cause of morbidity and mortality in end-stage renal disease. The aim of this study was to elucidate the frequency of traditional and novel cardiovascular and metabolic syndrome risk factors in patients with chronic kidney disease. Identification of these risk factors will allow for precautions to be taken earlier to prevent cardiovascular diseases and metabolic syndrome in chronic kidney disease patients.
\end{abstract}

Methods: A total of 214 patients (9I females, 123 males, mean age 56.I \pm 14.4 years) with chronic kidney disease who were followed in the Nephrology Department of Istanbul Goztepe Training and Research Hospital were included in the study. Anthropometric and biochemical measurements for cardiovascular risk factors and metabolic syndrome parameters were recorded. Glomerular filtration rates (GFR) were estimated using the Cockroft Gault formula. Metabolic syndrome was defined according to International Diabetes Federation criteria.

Results: Thirty-seven percent of patients with chronic renal failure were found to have three or more major cardiovascular risk factors. Seventy percent of patients were found to have metabolic syndrome. The mean numbers of major cardiovascular risk factors and metabolic syndrome parameters in patients with different GFR stages were: I.8 $\pm 1.0,2.6 \pm I .2\left(\right.$ GFR $<15 \mathrm{~mL} / \mathrm{min}$ per I.73 $\left.\mathrm{m}^{2}, \mathrm{n}=102\right)$;

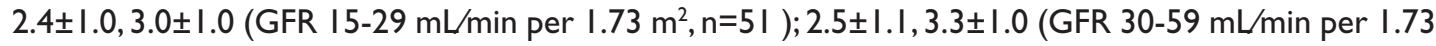
$\left.\mathrm{m}^{2}, \mathrm{n}=39\right) ; 2.4 \pm \mathrm{I}$. I , 3.5 \pm 0.7 (GFR $60-89 \mathrm{~mL} / \mathrm{min}$ per $\left.\mathrm{I} .73 \mathrm{~m}^{2}, \mathrm{n}=22\right)$, respectively $(P=.00 \mathrm{I})$.

Conclusion: Although the frequency of cardiovascular risk factors and metabolic syndrome were high in patients with chronic kidney disease, they were negatively correlated with the stage of renal failure.

Keywords: Cardiovascular risk factors; Chronic kidney disease; Metabolic syndrome

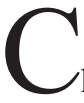
Caric Patients with end-stage renal disease are characterized by higher mortality rates than the general population. ${ }^{1}$ Mortality from cardiovascular disease (CVD) is 10 to 20 times higher among patients treated with long-term hemodialysis or peritoneal dialysis than in the general U.S. population. ${ }^{2}$ The burden of classic and novel cardiovascular $(\mathrm{CV})$ risks in individuals with earlier-stage kidney dysfunction is understudied in the general population. ${ }^{3}$ The majority of deaths are due to CVD in end-stage renal disease patients, and CVD is also a significant cause of morbidity and acute hospitalization in these patients. ${ }^{4}$ As a result, a combination of complications of CKD and accelerated CVD in these patients results in high rates of death. Some traditional CV

Received: October 5, 2009

Revised: December 28, 2009

Accepted: March 24, 2010

doi: $|0.3| 2 \mid / \mathrm{cmr} .2010 .892$ 
Table 1. Number, gender and age of the patients according to GFR groups.

\begin{tabular}{|c|c|c|c|c|}
\hline & & Male & Female & Age, y \\
\hline GFR & N (\%) & n (\%) & n (\%) & Mean \pm SD \\
\hline$<15$ & $102(47.7)$ & $60(58.8)$ & 42 (41.2) & $53.0 \pm 15.1$ \\
\hline $15-29$ & $51(23.8)$ & 25 (49.0) & 26 (51.0) & $60.1 \pm 14.3$ \\
\hline $30-59$ & 39 (18.2) & $24(61.5)$ & 15 (38.5) & $59.3 \pm 12.1$ \\
\hline $60-89$ & 22 (10.3) & 14 (63.6) & $8(36.4)$ & $54.5 \pm 14.2$ \\
\hline Total & 214 (100) & $123(57.5)$ & 91 (42.5) & $56.0 \pm 14.6$ \\
\hline
\end{tabular}

risk factors are male gender, hypertension, diabetes mellitus, high low-density (LDL) cholesterol, low high-density (HDL) cholesterol, physical inactivity, high body mass index (BMI), and obesity. These are evident in patients with or without renal disease. ${ }^{5}$

Metabolic Syndrome has been recognized as a possible risk factor for renal damage, and the increased prevalence of both metabolic syndrome and renal disease justifies the increasing interest within the nephrology community toward metabolic syndrome as another possible inducing cause of $\mathrm{CKD}$, although the available evidence of a direct causal relationship between metabolic syndrome and development of renal disease is scanty so far. ${ }^{6}$ Kurella et $\mathrm{al}^{7}$ concluded that metabolic syndrome is a risk factor for the development of diabetes and CVD; however, no prospective studies have examined metabolic syndrome as a risk factor for CKD. Recently, a few population-based studies have been published. ${ }^{8-10}$

An increasing number of patients with CKD either require renal replacement therapy or may suffer from concomitant cardiovascular events. Improvement of CV risk factors may enhance the health quality of patients with CKD and decrease morbidity and mortality rates. The aim of this study was to determine metabolic syndrome frequency and CV risk factor profiles of patients with varying degrees of renal failure.

\section{Methods}

Data of the participants were collected from the Nephrology
Department of Istanbul Goztepe Training and Research Hospital, Turkey. A total of 214 patients with CKD (91 females, 123 males, mean age $56.10 \pm 14.4$ years) were included in the study. Patients followed in the Nephrology Department were evaluated with respect to their demographic, anthropometric data, physical examination, laboratory findings, and therapeutic details to assess the presence of CV risk factors and metabolic syndrome. Participants were enrolled from 2005 to 2007 . The study was designed as a retrospective chart review. Glomerular filtration rates (GFR) were estimated using the Cockroft Gault formula: (140-age) $\times$ weight $(\mathrm{kg}) / 72 \times$ serum creatinine $(\mathrm{mg} / \mathrm{dL}) \times 0.8$ (if female). Patients with GFR $<90 \mathrm{~m} / \mathrm{min}$ per $1.73 \mathrm{~m}^{2}$ body surface area were included in the study. Kidney function was classified on the basis of the five estimated GFR ranges suggested by the National Kidney Foundation Practice Guidelines for Chronic Kidney Disease. ${ }^{11}$ Four groups of patients were analyzed according to their GFR levels and assigned to GFR stages according to the National Kidney Foundation ${ }^{11}$ as follows: Stage 2, kidney damage (diagnosed with imaging studies and urine tests [eg, proteinuria]) with mildly decreased GFR $\left(60-89 \mathrm{~m} / \mathrm{min}\right.$ per $\left.1.73 \mathrm{~m}^{2}\right)$; Stage 3 , moderately decreased GFR (30-59 $\mathrm{ml} / \mathrm{min}$ per $\left.1.73 \mathrm{~m}^{2}\right)$; Stage 4 , severely decreased GFR $\left(15-29 \mathrm{~m} / \mathrm{min}\right.$ per $\left.1.73 \mathrm{~m}^{2}\right)$; and Stage 5, kidney failure GFR $\left(<15 \mathrm{ml} / \mathrm{min}\right.$ per $\left.1.73 \mathrm{~m}^{2}\right)$.

The total number of $\mathrm{CV}$ risk factors were determined according to the following items: current cigarette smoking, hypertension (systolic blood pressure $>140 \mathrm{~mm} \mathrm{Hg}$ or diastolic blood pressure $>90 \mathrm{~mm} \mathrm{Hg}$ and/or being on antihypertensive therapy), high LDL-cholesterol $(>160 \mathrm{mg} /$ dL), low HDL-cholesterol $(<35 \mathrm{mg} / \mathrm{dL})$, diabetes mellitus (fasting plasma glucose $\geq 126 \mathrm{mg} / \mathrm{dl}$ and/or being on antidiabetic therapy), and BMI $\geq 30 \mathrm{~kg} / \mathrm{m}^{2}$.

Metabolic syndrome is defined according to the existence of three or more of the following criteria: (1) abdominal obesity with waist circumference $>94 \mathrm{~cm}$ for men or $>80 \mathrm{~cm}$ for women; (2) triglyceride $\geq 150 \mathrm{mg} / \mathrm{dL}$; (3) HDLcholesterol $<40 \mathrm{mg} / \mathrm{dL}$ for men or $<50 \mathrm{mg} / \mathrm{dL}$ for women; (4) blood pressure $\geq 13085 \mathrm{mmHg}$, (5) fasting plasma glucose $\geq 100 \mathrm{mg} / \mathrm{dL} .{ }^{12}$

Table 2. Association between cardiovascular risk factors and GFR stages.

\begin{tabular}{|c|c|c|c|c|c|}
\hline \multirow[b]{2}{*}{ CV Risk Factors } & \multicolumn{4}{|c|}{ GFR } & \multirow[b]{2}{*}{$P^{*}$} \\
\hline & $\begin{array}{c}<15 \\
n(\%)\end{array}$ & $\begin{array}{l}15-29 \\
n(\%)\end{array}$ & $\begin{array}{l}30-59 \\
\text { n (\%) }\end{array}$ & $\begin{array}{l}60-89 \\
n(\%)\end{array}$ & \\
\hline Hypertension $(n=171)$ & $67(65.7)$ & $46(90.2)$ & $39(100)$ & 19 (86.4) & .001 \\
\hline Hyperlipidemia ( $n=60)$ & $20(19.6)$ & $16(31.4)$ & $16(41.0)$ & $8(36.4)$ & .048 \\
\hline Diabetes mellitus $(n=70)$ & $30(29.4)$ & $16(31.4)$ & $17(43.6)$ & $7(31.8)$ & .449 \\
\hline Smoking $(n=31)$ & $14(13.7)$ & $8(15.7)$ & 6 (15.4) & $3(13.6)$ & .980 \\
\hline Low HDL (n=82) & $40(39.2)$ & $24(47.1)$ & $11(28.2)$ & $7(31.8)$ & .173 \\
\hline Obesity $(n=41)$ & $8(7.8)$ & $13(25.5)$ & $10(25.6)$ & $8(36.4)$ & .001 \\
\hline
\end{tabular}

GFR: glomerular filtration rate; CV: cardiovascular.

${ }^{*}$ chi-square test

136 CV risk factors and metabolic syndrome in CKD 
Table 3. Association between the number of the cardiovascular risk factors and GFR stages.

\begin{tabular}{|c|c|c|c|c|c|}
\hline \multirow[b]{3}{*}{ CV risk factors (n) } & \multicolumn{4}{|c|}{ GFR } & \multirow[b]{3}{*}{ Total (\%) } \\
\hline & $<15$ & $15-29$ & $30-59$ & $60-89$ & \\
\hline & n (\%) & n (\%) & n (\%) & n (\%) & \\
\hline 0 & $12(11.8)$ & - & - & $1(4.5)$ & $13(6.1)$ \\
\hline 1 & $30(29.4)$ & $11(21.6)$ & $9(23.1)$ & 4 (18.2) & $54(25.2)$ \\
\hline 2 & 34 (33.3) & 17 (33.3) & $10(25.6)$ & 7 (31.8) & 68 (31.8) \\
\hline 3 & $23(22.5)$ & $15(29.4)$ & $11(28.2)$ & $6(27.3)$ & $55(25.7)$ \\
\hline 4 & $3(2.9)$ & $7(13.7)$ & $8(20.5)$ & 4 (18.2) & $22(10.3)$ \\
\hline 5 & - & $1(2.0)$ & $1(2.6)$ & - & $2(0.9)$ \\
\hline Total & $102(100)$ & $51(100)$ & $39(100)$ & $22(100)$ & $214(100)$ \\
\hline
\end{tabular}

GFR: glomerular filtration rate; $\mathrm{CV}$ : cardiovascular.

*Likelihood ratio: $P=.004$

Statistical analysis was performed by SPSS 12.0 (Statistical Package for Social Sciences, Chicago IL, USA). Results were expressed as mean, standard deviation, and median. Categoric data were represented as numbers and percents. For the purpose of analysis of the differences between groups MannWhitney U-test, Kruskal-Wallis test and Mann-Whitney U-test with Bonferroni correction for post hoc analysis were used. Alpha significance was analysed by application of Bonferroni correction. Chi-square test was used to analyze associations in discrete variables between the groups. We considered $P$ values of $<.05$ to be statistically significant.

\section{Results}

A total of 214 patients were included in the study (91 females, 123 males, mean age $56.10 \pm 14.4$ years). Ninty-nine of the patients $(45.46 \%)$ were receiving either peritoneal dialysis or hemodialysis. Mean waist circumference was $95.05 \pm 15.23$ $\mathrm{cm}(52-150 \mathrm{~cm})$; mean BMI was $25.7 \pm 5.3 \mathrm{~kg} / \mathrm{m}^{2}(15.2-45.4$ $\left.\mathrm{kg} / \mathrm{m}^{2}\right)$. One-hundred fifty-five $(70.1 \%)$ patients were receiving antihypertensive therapy, $53(24.0 \%)$ patients were receiving antilipemic therapy, and 45 (20.4\%) patients were receiving antidiabetic therapy.

The number, gender, and age of the patients according to their GFR groups are shown in table 1. Participants with estimated GFR values between $15-29 \mathrm{~m} / \mathrm{min}$ per $1.73 \mathrm{~m}^{2}$ and $30-59$ $\mathrm{m} / \mathrm{min}$ per $1.73 \mathrm{~m}^{2}$ were older than the participants with GFR $<15 \mathrm{~m} /$ min per $1.73 \mathrm{~m}^{2}(P=.010, P=.022$, respectively).

\section{Association Between GFR Stages and Cardiovascular Risk Factors}

Hypertensive patients constituted $86.4 \%$ of the study group, $27 \%$ of the patients were hyperlipidemic, and diabetic patients constituted $32.6 \%$ of total patients. Thirty-two (14.5\%) patients were current smokers, and HDL-cholesterol was lower than $40 \mathrm{mg} / \mathrm{dL}$ in $86(40 \%)$ patients. Estimated BMI was higher than $30 \mathrm{~kg} / \mathrm{m}^{2}$ in 41 patients.

The patients with GFR values between $30-59 \mathrm{ml} / \mathrm{min}$ per 1.73 $\mathrm{m}^{2}$ were obviously more prone to have hypertension than the

Table 4. Association between metabolic syndrome parameters and GFR stages.

\begin{tabular}{|c|c|c|c|c|c|}
\hline \multirow[b]{2}{*}{ MS parameters } & \multicolumn{4}{|c|}{ GFR } & \multirow[b]{2}{*}{$P^{*}$} \\
\hline & $\begin{array}{l}<15 \\
n(\%)\end{array}$ & $\begin{array}{l}15-29 \\
n(\%)\end{array}$ & $\begin{array}{l}30-59 \\
\text { n (\%) }\end{array}$ & $\begin{array}{l}60-89 \\
\text { n (\%) }\end{array}$ & \\
\hline \multicolumn{6}{|l|}{ Waist circumference } \\
\hline $\begin{array}{l}\text { Female }>80 \mathrm{~cm} \text {; Male }>94 \mathrm{~cm}) \\
(\mathrm{n}=136)\end{array}$ & $46(45.1)$ & 37 (72.5) & 33 (84.6) & 20 (90.9) & .001 \\
\hline $\begin{array}{l}\text { HDL-cholesterol } \\
\text { Female }<50 \mathrm{mg} / \mathrm{dl} \text {; Male }<40 \mathrm{mg} / \mathrm{dl} \\
(\mathrm{n}=105)\end{array}$ & $48(47.1)$ & $31(60.8)$ & $16(41.0)$ & $10(45.5)$ & .238 \\
\hline $\begin{array}{l}\text { Blood pressure } \geq 130 / 85 \mathrm{mmHg} \text { and/or being } \\
\text { on antihypertensive therapy } \\
(n=184)\end{array}$ & $76(74.5)$ & 48 (94.1) & 39 (100) & 21 (95.5) & .001 \\
\hline $\begin{array}{l}\text { Fasting plasma glucose } \geq 100 \mathrm{mg} / \mathrm{dl} \text { and/or } \\
\text { being on antidiabetic therapy } \\
(\mathrm{n}=118)\end{array}$ & $48(47.1)$ & 27 (52.9) & 27 (69.2) & $16(72.7)$ & .034 \\
\hline $\begin{array}{l}\text { Triglyceride } \geq 150 \mathrm{mg} / \mathrm{dl} \\
\quad(\mathrm{n}=85)\end{array}$ & $52(51.0)$ & $11(21.6)$ & 13 (33.3) & 9 (40.9) & .001 \\
\hline
\end{tabular}

GFR: glomerular filtration rate; MS: metabolic syndrome.

${ }^{*}$ chi-square test 
Table 5. Association between the number of metabolic syndrome parameters and GFR stages.

\begin{tabular}{|c|c|c|c|c|c|}
\hline \multirow[b]{2}{*}{ MS parameters, $\mathbf{n}$} & \multicolumn{4}{|c|}{ GFR } & \multirow[b]{2}{*}{ Total } \\
\hline & $<15$ & $15-29$ & $30-59$ & $60-89$ & \\
\hline 0 & $3(2.9 \%)$ & - & - & - & $3(1.4 \%)$ \\
\hline 1 & $14(13.7 \%)$ & $4(7.8 \%)$ & $3(7.7 \%)$ & - & $21(9.8 \%)$ \\
\hline 2 & $28(27.5 \%)$ & $10(19.6 \%)$ & $3(7.7 \%)$ & $3(13.6 \%)$ & $44(20.6 \%)$ \\
\hline 3 & $34(33.3 \%)$ & $22(43.1 \%)$ & 17 (43.6\%) & $6(27.3 \%)$ & 79 (36.9\%) \\
\hline 4 & 17 (16.7\%) & $11(21.6 \%)$ & $12(30.8 \%)$ & $13(59.1 \%)$ & $53(24.8 \%)$ \\
\hline 5 & $6(5.9 \%)$ & $4(7.8 \%)$ & $4(10.3 \%)$ & - & $14(6.5 \%)$ \\
\hline Total & $102(100 \%)$ & $51(100 \%)$ & $39(100 \%)$ & $22(100 \%)$ & $214(100 \%)$ \\
\hline
\end{tabular}

GFR: glomerular filtration rate; MS: metabolic syndrome.

*Likelihood Ratio: $P=.003$

patients with GFR values between $15-29 \mathrm{ml}$ min per $1.73 \mathrm{~m}^{2}$ and $60-89 \mathrm{~m} / \mathrm{min}$ per $1.73 \mathrm{~m}^{2}(P<.001)$ (table 2). But, fewer patients had hypertension in the GFR $<15 \mathrm{~m} / \mathrm{min}$ per $1.73 \mathrm{~m}^{2}$ group than other GFR groups. The group of patients with GFR $<15 \mathrm{~m} / \mathrm{min}$ per $1.73 \mathrm{~m}^{2}$ were less likely to have hyperlipidemia than other groups $(P=.048)$. No difference was found between other GFR groups according to hyperlipidemia $(P>0.05)$. There was also no significant difference between GFR groups with regard to being diabetic, a current smoker, or having low HDL-cholesterol level $(P>.05)$. The association between GFR groups and BMI was significant in GFR $60-89 \mathrm{~m} / \mathrm{min}$ per $1.73 \mathrm{~m}^{2}$ group and other groups $(P=.001)$. In the GFR $<15 \mathrm{~m} /$ min per $1.73 \mathrm{~m}^{2}$ group, obesity was significantly lower than the other groups $(P=.001)$.

Participants with one and two CV risk factors were more likely to have lower GFR (table 3). As GFR increased, the total number of patients who had more CV risk factors increased. So, there was a positive correlation between increasing GFR and the number of $\mathrm{CV}$ risk factors $(P=.004)$.

\section{Association Between GFR Stages and Metabolic Syndrome}

The number of the patients with waist circumference larger than $80 \mathrm{~cm}$ in women and $94 \mathrm{~cm}$ in men, and with GFR $<15$ $\mathrm{m} / \mathrm{min}$ per $1.73 \mathrm{~m}^{2}$ was less than the patients with other GFR stages $(P<.001)$. However, there was no significant difference between patients with GFR $15-29 \mathrm{~m} / \mathrm{min}$ per $1.73 \mathrm{~m}^{2}, 30-59$ $\mathrm{m} / \mathrm{min}$ per $1.73 \mathrm{~m}^{2}$, and $60-89 \mathrm{~m} / \mathrm{min}$ per $1.73 \mathrm{~m}^{2}$ when they were evaluated according to waist circumference. When HDL-cholesterol was evaluated as a metabolic syndrome

Table 6. Odds ratio of cardiovascular risk factors in groups GFR $<30$ and $\geq 30$.

\begin{tabular}{llcc}
\hline CV Risk Factor & $\boldsymbol{P}^{*}$ & OR & $\mathbf{C l}$ \\
\hline Hypertension & .001 & 6.844 & $2.03-23.07$ \\
Hyperlipidemia & .020 & 2.108 & $1.12-3.97$ \\
Diabetes mellitus & .192 & 1.509 & $0.81-2.80$ \\
Smoking & .810 & 1.110 & $0.47-2.60$ \\
Low HDL & .031 & 0.484 & $0.25-0.94$ \\
Obesity & .008 & 2.612 & $1.27-5.36$ \\
\hline
\end{tabular}

GFR: glomerular filtration rate; CV: cardiovascular; OR: odds ratio; $\mathrm{Cl}$ : confidence interval

*chi-square test parameter, no significant difference was found among any GFR stages $(P=.238)$. Patients with GFR values between $15-29 \mathrm{~m} / \mathrm{min}$ per $1.73 \mathrm{~m}^{2}, 30-59 \mathrm{~m} / \mathrm{min}$ per $1.73 \mathrm{~m}^{2}$, and $60-89 \mathrm{~m} / \mathrm{min}$ per $1.73 \mathrm{~m}^{2}$ were more prone to have hypertension than patients with GFR $<5 \mathrm{~m} / \mathrm{min}$ per $1.73 \mathrm{~m}^{2}(P<.001)$. Hyperglycemia was more frequent in patients with GFR values between $30-59 \mathrm{ml} / \mathrm{min}$ per $1.73 \mathrm{~m}^{2}$ and $60-89 \mathrm{ml} / \mathrm{min}$ per $1.73 \mathrm{~m}^{2}$ than the patients in other GFR stages $(P=.034)$. Triglyceride levels were significantly higher in the patients with GFR $<15 \mathrm{ml} / \mathrm{min}$ per $1.73 \mathrm{~m}^{2}$ than in the patients in other GFR groups $(P=.001)$ (table 4$)$.

The number of metabolic syndrome parameters was positively correlated with increasing GFR (table 5). This association was considered statistically significant $(P=.003)$. Odds ratio of the risk factors were represented in table 6 . Median number of $\mathrm{CV}$ risk factors and metabolic syndrome parameters increased with GFR (table 7).

\section{Discussion}

As GFR increases, the total number of the patients having more CV risk factors increases, and metabolic syndrome is significantly lower in patients with GFR $<15 \mathrm{~m} / \mathrm{min}$ per 1.73 $\mathrm{m}^{2}$. When risk factors for CVD and metabolic syndrome parameters were evaluated individually, we found that triglyceride levels increased with decreasing GFR. Elevated serum triglyceride is caused by the accumulation of triglyceride rich lipoproteins such as very low density protein and intermediate density lipoprotein. ${ }^{13}$

Patients whose LDL-cholesterol levels are higher than 160 $\mathrm{mg} / \mathrm{dL}$ are more likely to have higher GFR than patients who have normal LDL-cholesterol levels. Sarnak et a ${ }^{14}$ similarly described the relationship between dyslipidemia and GFR, particularly regarding hypertriglyceridemia. As GFR declines, triglyceride levels increase. Kasiske et $\mathrm{a}^{15}$ concluded that hemodialysis patients with GFR $<15 \mathrm{~m} / \mathrm{min}$ per $1.73 \mathrm{~m}^{2}$ tend to have LDL-cholesterol levels similar to the general population. In end-stage renal disease patients, LDLcholesterol is usually reduced or within the normal range. ${ }^{16}$

About $86 \%$ of our patients were hypertensive and/or on antihypertensive therapy, similiar to the studies of Coresh et $\mathrm{al}^{17}$ and Buckalew et al. ${ }^{18}$ About $77 \%$ of the patients were 
Table 7. Mean and median number of the cardiovascular risk factors and metabolic syndrome parameters.

\begin{tabular}{|c|c|c|c|c|c|}
\hline \multirow[b]{2}{*}{ GFR } & \multirow[b]{2}{*}{$\mathbf{N}$} & \multicolumn{2}{|c|}{ CV risk factors (n) } & \multicolumn{2}{|c|}{ MS parameters (n) } \\
\hline & & Mean \pm SD & Median & Mean \pm SD & Median \\
\hline$<15$ & 102 & $1.8 \pm 1.0$ & 2 & $2.6 \pm 1.2$ & 3 \\
\hline $15-29$ & 51 & $2.4 \pm 1.0$ & 2 & $3.0 \pm 1.0$ & 3 \\
\hline $30-59$ & 39 & $2.5 \pm 1.1$ & 3 & $3.3 \pm 1.0$ & 3 \\
\hline $60-89$ & 22 & $2.4 \pm 1.1$ & 2 & $3.5 \pm 0.7$ & 4 \\
\hline Total & 214 & $2.1 \pm 1.1$ & 2 & $2.9 \pm 1.1$ & 3 \\
\hline
\end{tabular}

Kruskal-Wallis test: $P=.001$.

GFR: glomerular filtration rate; CV: cardiovascular; MS: metabolic syndrome; SD: standard deviation

using one or two antihypertensive agents. Most commonly used antihypertensive agents were calcium channel blockers, angiotensin-converting enzyme inhibitors, and angiotensin receptor blockers $(40 \%, 24 \%$, and $18 \%$ respectively). While $95 \%$ of the patients with GFR values of $60-89 \mathrm{ml}$ min per $1.73 \mathrm{~m}^{2}$ had hypertension, only $75 \%$ of patients with GFR of $<15 \mathrm{~m} / \mathrm{min}$ per $1.73 \mathrm{~m}^{2}$ had hypertension. The prevalence of hypertension increases as GFR increases. There is a positive relationship between hypertension and GFR. Although Sarnak et $\mathrm{al}^{14}$ declared an inverse relationship with systolic blood pressure and level of GFR, diastolic blood pressure was not significantly associated with GFR. The study called the Modification of Diet in Renal Disease Study (MDRD) $)^{18}$ included subjects with GFR values between $25-55 \mathrm{ml} / \mathrm{min}$ per $1.73 \mathrm{~m}^{2}$ as well as those between $13-24 \mathrm{ml}$ min per $1.73 \mathrm{~m}^{2}$. Patients with GFR values between $30-59 \mathrm{ml} / \mathrm{min}$ per $1.73 \mathrm{~m}^{2}$ had the highest rate of hypertension either systolic or diastolic. This group of patients were older than the patients with GFR $<15 \mathrm{ml}$ min per $1.73 \mathrm{~m}^{2}$. Foley et $\mathrm{al}^{3}$ did not find any association between higher levels of blood pressure and low GFR stage. Wheeler et $\mathrm{al}^{19}$ concluded that patients with more severely impaired renal function had lower diastolic pressure, in contrast to Sarnak et $\mathrm{al}^{14}$ who found no significant association between diastolic blood pressure and GFR. In our study population, patients who were on renal replacement therapy were more lean than the patients in the other groups, so this might influence our results on hypertension.

Approximately $33 \%(n=70)$ of the patients in our study had diabetes mellitus, while $24 \%$ had diabetic kidney disease $(n=51)$. Tonelli et $\mathrm{al}^{20}$ reported that about $37.5 \%$ of CKD patients had diabetes mellitus and the presence of diabetes was associated with CVD in CKD stages 1 through 4. Diabetes mellitus is the cause of end-stage renal disease in approximately $40 \%$ of cases in the United States. Diabetic patients were equally distributed among GFR stages. In our study, mean fasting plasma glucose of the diabetic patients was $168.4 \mathrm{mg} / \mathrm{dL} \pm 87.6 \mathrm{mg} / \mathrm{dL}$ and mean $\mathrm{HbA} 1 \mathrm{c}$ level of these patients was $8 \pm 3.0 \%$. Mean fasting plasma glucose of the nondiabetic patients was $98.9 \pm 22.2 \mathrm{mg} / \mathrm{dL}$, and mean $\mathrm{HbA} 1 \mathrm{c}$ level was $5.7 \pm 1.3 \%$. Menon et $\mathrm{al}^{21}$ concluded that $\mathrm{HbA} 1 \mathrm{c}$ was associated with increased mortality in nondiabetic kidney disease and a predictor of all-cause mortality. Despite this association between strict glycemic control and reduction in CVD mortality, morbidity rates have not been examined with randomized trials.
Approximately $14 \%$ of our patients were current smokers. In the CHOICE study, about $18 \%$ of the patients were current smokers on dialysis. ${ }^{22}$ Smoking has been linked to progression of kidney disease and of CVD in patients with reduced GFRs. ${ }^{23,24}$

Patients with GFR $<15 \mathrm{~m} / \mathrm{min}$ per $1.73 \mathrm{~m}^{2}$ and $15-29 \mathrm{ml}$ min per $1.73 \mathrm{~m}^{2}$ had lower HDL-cholesterol levels than patients in the other GFR groups. But this result was not found to be statistically significant $(P>.05)$. This result was parallel to the results of Wheeler et al, ${ }^{19}$ who concluded that patients with more severely impaired renal function had lower HDL-cholesterol levels. Despite an HDL-cholesterol level cut-off value of $35 \mathrm{mg} / \mathrm{dL}$ in the MDRD study, Sarnak et al ${ }^{14}$ found that HDL-cholesterol was positively correlated with GFR stage.

Chen et $\mathrm{a}^{25}$ examined a subsample of the National Health and Nutrition Examination Survey (NHANES) III population for the association between metabolic syndrome and risk for CKD. They compared the proportion of the participants with CKD among those with or without each component of metabolic syndrome. They concluded that elevated blood pressure, serum triglyceride, and plasma glucose were significantly associated with increased prevalence of CKD. Low HDL-cholesterol and abdominal obesity were significantly associated with increased prevalence of CKD. The patients in this study were not classified according to their GFR stages. Patients with GFR $<15 \mathrm{ml} / \mathrm{min}$ per $1.73 \mathrm{~m}^{2}$ were more malnourished than the patients in the other groups, so they had lower waist circumference and their fasting plasma glucose levels were lower than the patients with GFR $<30$ $\mathrm{m} / \mathrm{min}$ per $1.73 \mathrm{~m}^{2}$. Diabetic patients were prone to hypoglycemia due to advanced renal failure.

We found that the number of CV risk factors and metabolic syndrome parameters increased with increasing GFR. Subjects with one and two risk factors were especially more likely to have lower GFR levels. Our patients were from the Nephrology Department, so patient distribution was in a homogenous manner according to their GFR stages. Because uremia is a major risk factor for accelerated and atherosclerotic $\mathrm{CV}$ complications, dialysis procedures through bioincompatibility constitute an additional risk factor. ${ }^{26}$ Tonelli et $\mathrm{al}^{20}$ reported that CVD was common in the predialysis population, and its prevalence increased with more severe kidney failure. 
However, that study population consisted of patients who had creatinine clearances of $75 \mathrm{ml} / \mathrm{min}$ per $1.73 \mathrm{~m}^{2}$ or less but were not on dialysis therapy. Patients with GFR $<15 \mathrm{ml} / \mathrm{min}$ per $1.73 \mathrm{~m}^{2}$ were less obese and had the lowest waist circumference, so there was not a strong association with other CV risk factors and metabolic syndrome parameters. Our data showed that patients were undertreated for their hypertension, high LDL-cholesterol, and diabetes (eg, HbA1c level was $8.4 \pm 3.0 \%$ ).

In the ARIC (Atherosclerosis Risk in Communities) study, ${ }^{27}$ patients were classified according to their GFR stages, but patients with GFR $<15 \mathrm{~m} / \mathrm{min}$ per $1.73 \mathrm{~m}^{2}$ were not included in the study, and patients with GFR values between 15-59 $\mathrm{ml} / \mathrm{min}$ per $1.73 \mathrm{~m}^{2}$ constituted only $2 \%$ of the study population. When basic characteristics of the patients were evaluated, atherosclerotic CVD risk factors were found to be higher in the group with lower baseline GFR. In our study, $48 \%$ of the patients had GFR $<15 \mathrm{~m} / \mathrm{min}$ per $1.73 \mathrm{~m}^{2}$, and all patients were followed by the physicians in the Nephrology Department.

When the results were evaluated totally, patients with GFR $>30 \mathrm{ml}$ min per $1.73 \mathrm{~m}^{2}$ had more hypertension, hyperlipidemia, and obesity. Lower BMI and cholesterol levels in patients with GFR $<30 \mathrm{ml}$ min per $1.73 \mathrm{~m}^{2}$ were assumed to be due to malnutrition. These factors can be responsible for unfavorable outcomes in these patients with a spectrum of hemodialysis related risk factors named malnutrition-inflammation complex syndrome (MICS). Recent research has shown that several components of MICS, alone or in combination, are predictors of mortality in hemodialysis patients. ${ }^{28}$ Kalantar-Zadeh et al ${ }^{29}$ estimated the relative risk of mortality in a hypotethical model that was based on the state of nutrition and serum cholesterol levels. It appeared that in underweight patients mortality is influenced by hypocholestrolemia. Takeda et $\mathrm{al}^{30}$ also failed to show an association between hypertension and mortality in hemodialysis patients. Fleischmann et $\mathrm{al}^{31}$ concluded that conventional risk factors over at least a twoyear period did not readily account for the higher mortality of a group of predominatly African-American patients on hemodialysis. It is also claimed that greater fluid retention between two subsequent hemodialysis treatment sessions is associated with higher risk of all-cause and cardiovascular death. ${ }^{32}$ Heart failure is the most common cause of early death in patients on dialysis. ${ }^{33}$ So, end-stage renal disease patients do not die as often of myocardial infarctions, but rather from sudden cardiac death and congestive heart failure.

\section{Conclusion}

The results of this study indicate that the number of the CV risk factors and metabolic syndrome frequency increases with increasing GFR. High frequency of CV risk factors among these patients suggests that cardiovascular disease begins in earlier stages of renal failure; therefore, implementation of risk factor reduction strategies earlier and agressively in the course of renal failure may provide an opportunity to prevent
CVD in CKD patients who also suffer from dialysis-related risk factors.

\section{References}

1. Barrett BJ, Parfrey PS, Morgan J, Barré P, Fine A, Goldstein MB, Handa SP, Jindal KK, Kjellstrand CM, Levin A, Mandin $\mathrm{H}$, Muirhead N, Richardson RM. Prediction of early death in end- stage renal disease patients starting dialysis. Am J Kidney Dis 1997;29:214-222.

2. Foley RN, Parfrey PS, Sarnak MJ. Clinical epidemiology of cardiovascular disease in chronic renal disease. Am J Kidney Dis 1998;32:S112-119.

3. Foley RN, Wang C, Collins AJ. Cardiovascular risk factor profiles and kidney function stage in the US general population: the NHANES III study. Mayo Clin Proc 2005;80:1270-1277.

4. Guerin AP, Blacher J, Pannier B, Marchais SJ, Safar ME, London GM. Impact of aortic stiffness attenuation on survival of patients in end-stage renal failure. Circulation 2001;103:987-992.

5. Covic A, Gusbeth-Tatomir P, Goldsmith D. The challenge of cardiovascular risk factors in end-stage renal disease. J Nephrol 2003;16:476-486.

6. Calò LA. Impact of metabolic syndrome on chronic kidney disease. [Article in Italian] Minerva Med 2006;97:451-459.

7. Kurella M, Lo JC, Chertow GM. Metabolic syndrome and the risk for chronic kidney disesase among nondiabetic adults. J Am Soc Nephrol 2005; 16:2134-2140.

8. Kitiyakara C, Yamwong S, Cheepudomwit S, Domrongkitchaiporn S, Unkurapinun N, Pakpeankitvatana V, Sritara P. The metabolic syndrome and chronic kidney disease in a Southeast Asian cohort. Kidney Int 2007; 71:693-700.

9. Tanaka H, Shiohira Y, Uezu Y, Higa A, Iseki K . Metabolic syndrome and chronic kidney disease in Okinawa, Japan. Kidney Int 2006;69:369-374.

10. Ninomiya T, Kiyohara Y, Kubo M, Yonemoto K, Tanizaki Y, Doi Y, Hirakata H, Iida M. Metabolic syndrome and CKD in a general Japanese population: the Hisayama Study. Am J Kidney Dis 2006;48:383-391.

11. Levey AS, Coresh J, Balk E, Kausz AT, Levin A, Steffes MW, Hogg RJ, Perrone RD, Lau J, Eknoyan G; National Kidney Foundation. National Kidney Foundation practice guidelines for chronic kidney disease: evaluation, classification, and stratification. Ann Intern Med 2003;139:137-147.

12. Grundy SM, Cleeman JI, Daniels SR, Donato KA, Eckel RH, Franklin BA, Gordon DJ, Krauss RM, Savage PJ, Smith SC Jr, Spertus JA, Costa F; American Heart Association; National Heart, Lung, and Blood Institute. Diagnosis and management of the metabolic syndrome: an American Heart Association/National Heart, Lung, and Blood Institute scientific statement. Circulation 2005;112:2735-2752.

13. Shoji T, Nishizawa Y. Plasma lipoprotein abnormalities in hemodialysis patients clinical implications and therapeutic guidelines. Ther Apher Dial 2006;10:305-315.

14. Sarnak MJ, Coronado BE, Greene T, Wang SR, Kusek JW, Beck GJ, Levey AS. Cardiovascular disease risk factors in chronic renal insufficiency. Clin Nephrol 2002;57:327-335.

15. Kasiske BL. Hyperlipidemia in patients with chronic renal disease. Am J Kidney Dis 1998;32:S142-156.

16. Shoji T, Ishimura E, Inaba M, Tabata T, Nishizawa $Y$. Atherogenic lipoproteins in end-stage renal disease. Am J Kidney Dis 2001;38:S30-33.

17. Coresh J, Wei GL, McQuillan G, Brancati FL, Levey AS, Jones C, Klag MJ. Prevalence of high blood pressure and elevated serum creatinine level in the United States: findings from the third National Health and Nutrition Examination Survey (1988-1994). Arch Intern Med 2001;161:1207-1216. 
18. Buckalew VM Jr, Berg RL, Wang SR, Porush JG, Rauch S, Schulman G. Prevalence of hypertension in 1,795 subjects with chronic renal disease: the modification of diet in renal disease study baseline cohort. Modification of Diet in Renal Disease Study Group. Am J Kidney Dis 1996;28:811-821.

19. Wheeler DC, Townend JN, Landray MJ. Cardiovascular risk factors in predialysis patients: baseline data from the Chronic Renal Impairment in Birmingham (CRIB) study. Kidney Int Suppl 2003;(84):S201-S203.

20. Tonelli M, Bohm C, Pandeya S, Gill J,Gill J, Levin A, Kiberd BA. Cardiac risk factors and the use of cardioprotective medications in patients with chronic renal insufficiency. Am J Kidney Dis 2001;37:484-489.

21. Menon V, Greene T, Pereira AA, Wang X, Beck GJ, Kusek JW, Collins AJ, Levey AS, Sarnak MJ. Glycosilated hemoglobin and mortality in patients with nondiabetic chronic kidney disease. J Am Soc Nephrol 2005;16:3411-3417.

22. Longenecker JC, Coresh J, Powe NR, Levey AS, Fink NE, Martin A, Klag MJ. Traditional cardiovascular disease risk factors in dialysis patients compared with the general population: the CHOICE Study. J Am Soc Nephrol 2002;13:1918-1927

23. Orth SR, Ritz E, Schrier RW. The renal risk of smoking. Kidney Int 1997;51:1669-1677.

24. Jungers P, Massy ZA, Nguyen Khoa T, Fumeron C, Labrunie M, Lacour B, Descamps-Latscha B, Man NK. Incidence and risk factors of atherosclerotic cardiovascular accidents in predialysis chronic renal failure patients : a prospective study. Nephrol Dial Transplant 1997;12:2597-2602.

25. Chen J, Muntner P, Hamm LL, Jones DW, Batuman V, Fonseca $\mathrm{V}$, Whelton PK, He J. The metabolic syndrome and chronic kidney disease in U.S. adults. Ann Intern Med 2004; 140:167-174.

26. Ritz E, Deppisch R, Stier E, Hansch G. Atherogenesis and cardiac death: are they related to dialysis procedure and biocompatibility? Nephrol Dial Transplant 1994; 9(Suppl 2):165-172.

27. Manjunath G, Tighiouart H, Ibrahim H, MacLeod B, Salem DN, Griffith JL, Coresh J, Levey AS, Sarnak MJ. Level of kidney function as a risk factor for atherosclerotic cardiovascular outcomes in the community. J Am Coll Cardiol 2003;41:47-55.

28. Kalantar-Zadeh K, Kopple JD, Block G, Humphreys MH. A malnutrition-inflammation score is correlated with morbidity and mortality in maintenance hemodialysis patients. Am J Kidney Dis 2001;38:1251-1263.

29. Kalantar-Zadeh K, Block G, Humphreys MH, Kopple JD. Reverse epidemiology of cardiovascular risk factors in maintenance dialysis patients. Kidney Int 2003;63:793-808.

30. Takeda A, Toda T, Fujii T, Shinohara S, Sasaki S, Matsui N. Discordance of influence of hypertension on mortality and cardiovascular risk in hemodialysis patients. Am J Kidney Dis $2005 ; 45: 112-118$.

31. Fleischmann EH, Bower JD, Salahudeen AK. Are conventional cardiovascular risk factors predictive of two-year mortality in hemodialysis patients? Clin Nephrol 2001;56:221-230.

32. Kalantar-Zadeh K, Regidor DL, Kovesdy CP, Van Wyck D, Bunnapradist S, Horwich TB, Fonarow GC. Fluid retention is associated with cardiovascular mortality in patients undergoing long-term hemodialysis. Circulation 2009;119:671-679.

33. Biesenbach G, Hubmann R, Janko O, Scmekal B, EichbauerSturm G. Predialysis management and predictors for early mortality in uremic patients who die within one year after initiation of dialysis therapy. Ren Fail 2002;24:197-205.

\section{Author Affilliations}

Gul Sagun, MD*; Gulcin Kantarci, $M D^{\dagger}$; Banu Mesci, $M D^{*}$; Sinem Gungor, MD*; Funda Turkoglu, MD*;

Elif Yorulmaz, MD*; Aytekin Oguz, MD*

\author{
*Department of Internal Medicine, Goztepe Training and \\ Research Hospital, Istanbul, Turkey \\ tDepartment of Nephrology, Goztepe Training and Research \\ Hospital, Istanbul, Turkey
}

